\title{
Regulation of biological activity of surfactants under cultivation of Acinetobacter calcoaceticus IMB B-7241 on glycerol
}

\author{
Tetiana Pirog ${ }^{1,2}$, Daria Lutsai ${ }^{1}$, Hanna Yarova ${ }^{1}$ \\ 1 - National University of Food Technologies, Kyiv, Ukraine \\ 2 - Institute of Microbiology and Virology of the NAS, Kyiv, Ukraine
}

Keywords:
Acinetobacter
calcoaceticus
IMV B-7241
Surfactants
Glycerol
Regulation
Properties

Article history:

Received

07.05.2021

Received in

revised form

21.11.2021

Accepted

30.12.2021

Corresponding

author:

Tetiana Pirog

E-mail:

tapirog@

nuft.edu.ua

DOI:

$10.24263 / 2304-$

974X-2021-10-4-

16

\section{Abstract}

Introduction. The aim of this research was to study the biological activity of surfactants synthesized by Acinetobacter calcoaceticus IMV B-7241 in the medium with glycerol of various degrees of purification and high content of calcium cations (activators of $\mathrm{NADH}^{+}$-dependent glutamate dehydrogenase, which is a key enzyme of biosynthesis of surface-active aminolipids responsible for antimicrobial activity of surfactant complex).

Materials and methods. Cultivation of A. calcoaceticus was carried out in liquid mineral medium using as substrates refined glycerol and the waste from biodiesel production. The base medium did not contain calcium chloride, the content of $\mathrm{CaCl}_{2}$ in the modified medium was 0.1 and $0.2 \mathrm{~g} / \mathrm{l}$. Surfactants were extracted from the supernatant of the culture luquid with a modified mixture of Folch. The number of adhered cells and the degree of biofilm destruction in the presence of surfactants was determined by spectrophotometric method, antimicrobial activity of surfactants - by the minimum inhibitory concentration (MIC).

Results and discussion. It was found that the additional introduction of $0.1-0.2 \mathrm{~g} / 1$ of $\mathrm{CaCl}_{2}$ into cultivation medium with refined glycerol was accompanied by the synthesis of surfactants, the MIC of which against bacteria (Bacillus subtilis BT-2, Enterobacter cloacae C-8, Staphylococcus aureus BMS-1) and yeast (Candida albicans D-6) were $1.01-21.3 \mu \mathrm{g} / \mathrm{ml}$ and were 1.4-29 times lower compared to the MIC of surfactants obtained in base medium $(1.83-58.8 \mu \mathrm{g} / \mathrm{ml})$. The adhesion of test cultures on abiotic materials treated with such surfactants was $8-13 \%$ lower, and the degree of biofilms destruction was 5-19\% higher compared to the values, established for surfactants obtained on base medium. The increasing antimicrobial and anti-adhesive activity of surfactants synthesized on waste of biodiesel production was observed only when $\mathrm{CaCl}_{2}$ was introduced into the medium at a concentration of $0.2 \mathrm{~g} / \mathrm{l}$. Surfactants synthesized in the presence of calcium cations in the medium with the waste of biodiesel production proved to be more effective destructors of bacterial biofilms in comparison with those obtained in the base medium only at low concentrations $(0.7-5.5 \mu \mathrm{g} / \mathrm{ml})$.

Conclusion. The results demonstrate the possibility of regulating the biological activity of $A$. calcoaceticus IMV B-7241 surfactants by changing in the composition of medium content of calcium cations activators of $\mathrm{NADH}^{+}$-dependent glutamate dehydrogenase (key enzyme of surface-active aminolipids biosynthesis). Surfactants synthesized under different cultivation conditions of A. calcoaceticus IMB B-7241 on glycerol are more effective biofilm destructors and antimicrobial and anti-adhesive agents compared to the known lipopeptides and rhamnolipids formed on glycerol. 


\section{Introduction}

The disadvantages of technologies for obtaining microbial surfactants, which due to a combination of unique physicochemical and biological properties are metabolites of a wide range of applications, are changes in these properties in different cultivation conditions, as well as the high cost of such microbial synthesis products (Sharma and Sharma, 2021; Shu et al., 2021).

One of the ways to increase the efficiency of microbial surfactant technologies is using cheap industrial waste as a substrate, waste of biodiesel production, in particular (Crosse et al., 2019). Interest in waste of biodiesel production is due to the fact that the problem today is the need to dispose of large amounts of toxic industrial waste. The most effective way to dispose of such waste is to use them as substrates in biotechnological processes to obtain practically valuable products (Diamantopoulou et al., 2020).

There is no data in the literature about ways to regulate the biological activity of surfactants under the cultivation of the producer and notes that the main approaches to regulating the biological properties of microbial surfactants are their post-fermentation chemical modification and improvement of producer strains by metabolic and genetic engineering (Pirog et al., 2019).

It was previously established that Acinetobacter calcoaceticus IMV B-7241 synthesizes a complex of surfactant amino- and glycolipids on a wide range of carbon substrates, including glycerol of various degrees of purification. A study of the biological activity of surfactants synthesized on the waste of biodiesel production showed that such surfactants proved to be less effective antimicrobial agents compared to those formed on refined glycerol (Pirog et al., 2018).

Our previous studies have shown that one of the approaches to increase the antimicrobial and anti-adhesive activity of microbial surfactants is to increment the content of activators of key enzymes of aminolipid biosynthesis - the most effective antimicrobial agents (Pirog et al., 2018; 2019; 2021).

Activators of $\mathrm{NADH}^{+}$-dependent glutamate dehydrogenase in strain $A$. calcoaceticus IMV B-7241 grown on refined glycerol are calcium cations. However, no activating effect of $\mathrm{Ca}^{2+}$ on the activity of this enzyme was detected during the cultivation of $A$. calcoaceticus IMV B-7241 on the waste of biodiesel production (Pirog et al., 2021)

In connection with the above, this work aimed to study the biological activity of surfactants synthesized by $A$. calcoaceticus IMV B-7241 in a medium with glycerol of different degrees of purification and higher content of calcium cations (activators of $\mathrm{NADH}^{+}$dependent glutamate dehydrogenase - key enzyme of biosynthesis of surfactant aminolipids).

\section{Materials and methods}

\section{Object of research}

The main object of research was a strain of oil-oxidizing bacteria, identified as Acinetobacter calcoaceticus K-4 and isolated from an oil-contaminated soil sample. Strain A. calcoaceticus K-4 is registered in the Depository of Microorganisms of the D.K. Zabolotny Institute of Microbiology and Virology of the National Academy of Sciences of Ukraine under the number IMV B-7241.

Bacterial strains (Bacillus subtilis BT-2, Enterobacter cloacae C-8, Staphylococcus aureus BMS-1) and yeast (Candida albicans D-6) from the collection of live cultures of the 
Department of Biotechnology and Microbiology of the National University of Food Technology were used as test cultures in determining the antimicrobial and anti-adhesive activity of surfactants, as well as their role in the destruction of biofilms.

\section{Medium composition and conditions of cultivation}

Strain A. calcoaceticus IMV B-7241 was grown in the medium (g/l): $\left(\mathrm{NH}_{2}\right)_{2} \mathrm{CO}-0.35$; $\mathrm{MgSO}_{4} \cdot 7 \mathrm{H}_{2} \mathrm{O}-0.1 ; \mathrm{NaCl}-1.0 ; \mathrm{Na}_{2} \mathrm{HPO}_{4}-0.6 ; \mathrm{KH}_{2} \mathrm{PO}_{4}-0.14 ; \mathrm{pH} 6.8-7.0$. Yeast autolysate $-0.5 \%(\mathrm{v} / \mathrm{v})$ and microelement solution $-0.1 \%(\mathrm{v} / \mathrm{v})$ were additionally added into the medium. The micronutrient solution contained $(\mathrm{g} / 100 \mathrm{ml}): \mathrm{ZnSO}_{4} \cdot 7 \mathrm{H}_{2} \mathrm{O}-1,1 ; \mathrm{MnSO}_{4}$ - $\mathrm{H}_{2} \mathrm{O}-0.6 ; \mathrm{FeSO}_{4} \cdot 7 \mathrm{H}_{2} \mathrm{O}-0.1 ; \mathrm{CuSO}_{4} \cdot 5 \mathrm{H}_{2} \mathrm{O}-0.004 ; \mathrm{CoSO}_{4} \cdot 7 \mathrm{H}_{2} \mathrm{O}-0.03 ; \mathrm{H}_{3} \mathrm{BO}_{3}-$ $0.006 ; \mathrm{KI}-0.0001$; EDTA (Trilon B) -0.5 .

\section{Modifications of the base medium:}

1. Adding of $\mathrm{CaCl}_{2}(0.1 \mathrm{~g} \mathrm{l})$,

2. Adding of $\mathrm{CaCl}_{2}(0.2 \mathrm{~g} / \mathrm{l})$.

As carbon sources used $(\%, v / v)$ : refined glycerol -3 , waste of biodiesel production 5. Concentrations of glycerol of different quality are equimolar on carbon.

As the inoculum was used culture in the exponential phase, grown in a medium of the above composition with $0.5 \%$ of the corresponding substrate. The inoculum with the number of bacteria $10^{4}-10^{5}$ cells $/ \mathrm{ml}$ was applied in an amount of $10 \%$ of the medium volume.

Cultivation of $A$. calcoaceticus IMV B-7241 was carried out in $750 \mathrm{ml}$ flasks with 100 $\mathrm{ml}$ of medium on a shaker $(320 \mathrm{rpm})$ at $30^{\circ} \mathrm{C}$ for 7 days.

\section{Determination of extracellular surfactant concentration}

The amount of extracellular surfactants was determined using our modified method of Bly and Dyer (Bligh and Dyer, 1959) after extraction with a mixture of chloroform and methanol (2:1) from the supernatant of the culture liquid. To obtain the supernatant, the culture liquid was centrifuged at $5000 \mathrm{~g}$ for 20 minutes.

We modified the classical solvent system (Folch mixture - the known Bly and Dyer method used to isolate surfactants allows to isolate mainly nonpolar lipids) by adding $1 \mathrm{n}$ $\mathrm{HCl}$ (chloroform-methanol $-1 \mathrm{n} \mathrm{HCl}=4: 3:$ ) because A. calcoaceticus IMV B-7241 synthesizes a complex of polar and non-polar lipids. This system allows to completely isolate both polar and non-polar lipids.

$25 \mathrm{ml}$ of supernatant was placed in a $100 \mathrm{ml}$ cylindrical separation glass-stoppered funnel, added $1 \mathrm{n} \mathrm{HCl}$ solution to achieve a pH of 4.0-4.5 (about $5 \mathrm{ml}$ ). The funnel was shaken for $3 \mathrm{~min}$, then added $15 \mathrm{ml}$ of chloroform and methanol (2:1) and shaken again (lipid extraction) for 5 minutes. The mixture obtained after extraction was left in a separation funnel for phase separation, after which the lower fraction was drained (organic extract 1), and the aqueous phase was subjected to re-extraction. Upon re-extraction, $1 \mathrm{n} \mathrm{HCl}$ solution was added to the aqueous phase to achieve a $\mathrm{pH}$ of 4.0-4.5 (about $5 \mathrm{ml}$ ), $15 \mathrm{ml}$ of a mixture of chloroform and methanol $(2: 1)$ and the lipids were extracted for 5 minutes. After phase separation, the lower fraction was drained to obtain organic extract 2 . In the third step, $25 \mathrm{ml}$ of a mixture of chloroform and methanol (2:1) was added to the aqueous phase, and extraction was carried out as described above for obtaining organic extract 3. Extracts 1-3 were combined and evaporated on a rotary evaporator IP- $1 \mathrm{M} 2$ at $50^{\circ} \mathrm{C}$ and an absolute pressure of 0.4 ATM to constant weight. 


\section{Obtaining surfactant preparations}

Solutions of A. calcoaceticus IMV B-7241 surfactants with various concentrations were used as preparations in the researches. For this, the dry surfactant residue was dissolved in sterile phosphate buffer $(0.1 \mathrm{M}, \mathrm{pH} 7.0)$ to the original volume $(25 \mathrm{ml})$ and then diluted with this buffer to the required concentration. Surfactant solutions were sterilized in an autoclave at $112^{\circ} \mathrm{C}$ for 30 minutes.

\section{Analysis of antimicrobial activity of surfactants}

The antimicrobial activity of surfactants was analyzed by the minimum inhibitory concentration (MIC) (Chebbi et al., 2017). Determination of MIC was carried out by the method of double serial dilutions in meat-peptone broth (MPB) for bacteria and liquid wort for yeast. $1 \mathrm{ml}$ of medium was added to 10 tubes, $1 \mathrm{ml}$ of a surfactant solution of a certain concentration was added to the first tube, then mixed, after that $1 \mathrm{ml}$ was taken and transferred to the next tube under sterile conditions. A similar dilution was performed for the next nine tubes. $1 \mathrm{ml}$ was taken from the last tube. Thus, the final volume in each tube was 1 $\mathrm{ml}$ (MPB or wort and surfactant solution), and the surfactant concentration in each next tube was reduced by 2 times. As a control, $1 \mathrm{ml}$ of MPB (for bacteria) or wort (for yeast) was used without the adding of surfactant solution. Next, $0.1 \mathrm{ml}$ of test culture suspension $\left(10^{5}-10^{6}\right.$ $\mathrm{CFU} / \mathrm{ml}$ ) was added to each tube and mixed. The tubes were incubated for $24 \mathrm{~h}$ at $28-30^{\circ} \mathrm{C}$ for bacteria and $24-26^{\circ} \mathrm{C}$ for yeast. The results were evaluated visually by the medium turbidity : $(+)$ - tubes, medium turbidity was observed (growth of the test culture), $(-)-$ there was no turbidity (no growth). The minimum inhibitory concentration of surfactant solution was defined as the surfactant concentration in the last tube where growth was absent.

\section{Determination of anti-adhesive activity of surfactants}

The anti-adhesive activity of surfactants was determined as described in (Rufino et al., 2011). Identical plates $\left(1 \mathrm{~cm}^{2}\right)$ of test materials (tile, steel, glass) were pre-cleaned with detergent, rinsed with distilled water, air-dried and sterilized at $112^{\circ} \mathrm{C}$ for 30 minutes. After sterilization, the plates were treated with a surfactant solution (in the control version - sterile phosphate buffer) and kept at $30^{\circ} \mathrm{C}$ for $18-24$ hours. Next, control and pre-treated surfactant materials were rinsed with sterile phosphate buffer or distilled water to remove residual preparations.

Test cultures of microorganisms were suspended in $100 \mathrm{ml}$ of sterile tap water, pretreated and untreated (control) materials were placed in the suspension and were kept for $2 \mathrm{~h}$ at $30^{\circ} \mathrm{C}$. Control and pre-treated materials were rinsed with phosphate buffer to wash away non-adherent cells. Materials with adherent cells were left to air dry, after which the adherent cells were fixed by placing the material first in methanol (99\%) for $15 \mathrm{~min}$ and stained in $1 \%$ gentian violet solution for $5 \mathrm{~min}$. The plates of the material were rinsed with tap water and left at room temperature to dry. Next, the coloured adherent cells were washed from the surface of the materials with $1 \mathrm{ml}$ of glacial acetic acid, made $9 \mathrm{ml}$ of distilled water and measured the optical density of the resulting suspension spectrophotometrically using a wavelength of $540 \mathrm{~nm}$.

The number of adherent cells was defined as the ratio of the optical density of the suspension obtained after treatment of materials with surfactants to the optical density of the suspension obtained after treatment of materials with phosphate buffer (control) and expressed as a percentage. 


\section{Study of the degree of the biofilm destruction under the action of surfactants}

Determination of the effect of surfactants on the destruction of the biofilm was carried out as described in (Gomes et al., 2012). To obtain the biofilm, $180 \mu \mathrm{l}$ of MPB or liquid wort and $20 \mu \mathrm{l}$ of one-day test culture suspension were added to the polystyrene microplates, previously incubated for $24 \mathrm{~h}$ at the optimal temperature. Then the culture liquid was poured off and added another $180 \mu \mathrm{l}$ of fresh MPB or wort and $20 \mu \mathrm{l}$ of test culture suspension. Test culture suspensions were incubated for the next 24 hours. After $48 \mathrm{~h}$, the culture liquid was poured off, and $200 \mu \mathrm{l}$ solution with the different concentrations of surfactants was added to the microplate wells (with the biofilm of the test culture previously formed on them). In the control variants (wells) sterile tap water $(200 \mu \mathrm{l})$ was added instead of surfactants. After exposure, the wells were washed three times with $200 \mu \mathrm{l}$ of distilled water and the number of adherent cells was determined spectrophotometrically. The degree of biofilm destruction (\%) was determined as the difference between cells adhesion in untreated and surfactant wells of the polystyrene plate.

\section{Statistical analysis}

All experiments were performed in 3 replicates, the number of parallel determinations in the experiments was 3-5. Statistical processing of experimental data was carried out as described in previous papers (Pirog et al., 2018). The differences in averages were considered reliable at the level of significance $\mathrm{p}<0.05$.

\section{Results and discussion}

\section{Effect of the concentration of activators of $\mathrm{NADH}^{+}$-dependent glutamate dehydrogenase in the culture medium on antimicrobial synthesized surfactants}

The table 1 shows the minimum inhibitory concentrations of the strain IMV B-7241 surfactants, synthesized in a medium with different concentrations of calcium chloride. The results of the studies showed that the cultivation of $A$. calcoaceticus IMV B-7241 in medium with refined glycerol and different concentrations of $\mathrm{CaCl}_{2}$ was accompanied by the synthesis of surfactants with increased antimicrobial activity. Thus, the minimum inhibitory concentrations of such surfactants $(1.01-21.3 \mu \mathrm{g} / \mathrm{ml})$ were $1.4-29$ times lower than the MIC surfactants obtained in the base medium $(1.83-58.8 \mu \mathrm{g} / \mathrm{ml})$.

However, the data in table 1 , show that the antimicrobial activity of surfactants synthesized in the presence of $0.1 \mathrm{~g} / 1 \mathrm{CaCI}_{2}$ in the medium with the waste of biodiesel production was lower than the surfactants obtained on the base medium (MIC relative to the test cultures was $44.4-355$ and $29.7-59.5 \mu \mathrm{g} / \mathrm{ml}$, respectively). In our opinion, one of the reasons for the lower antimicrobial activity of surfactants synthesized on waste of biodiesel production is the presence of potassium and sodium cations in these wastes, which may be potential inhibitors of $\mathrm{NADH}^{+}$-dependent glutamate dehydrogenase $A$. calcoaceticus IMV B7241.

At the same time, the adding of $0.2 \mathrm{~g} / 1$ of calcium chloride into the medium with the waste of biodiesel production was accompanied by the synthesis of surfactants with higher antimicrobial activity compared with thoses synthesized on the medium with $0.1 \mathrm{~g} / 1 \mathrm{CaCl}_{2}$ (14.7-29.4 and 44.4-355 $\mu \mathrm{g} / \mathrm{ml}$, respectively, see Table 1). Moreover, the minimum inhibitory concentrations for B. subtilis BT-2 and E. cloacae C-8 surfactants synthesized in 
the presence of $0.2 \mathrm{~g} / 1$ of calcium chloride did not differ from those established for surfactants obtained on the base medium with the waste of biodiesel production $(29.4-29.7 \mu \mathrm{g} / \mathrm{ml})$, and the MIC for $S$. aureus BMS-1 and C. albicans D-6 such surfactants were even 4 times lower than the MIC of preparations synthesized in the base medium $(14.7$ and $59.5 \mu \mathrm{g} / \mathrm{ml}$, respectively) (Table 1).

Table 1

Antimicrobial activity of $A$. calcoaceticus IMV B-7241 surfactants, synthesized in a medium with different concentrations of calcium cations

\begin{tabular}{|c|c|c|c|c|c|}
\hline \multirow{3}{*}{$\begin{array}{c}\text { Carbon } \\
\text { source }\end{array}$} & \multirow{2}{*}{$\begin{array}{c}\text { Concentration of } \\
\text { CaCl } \mathbf{2} \text { in the } \\
\text { medium, } \mathbf{g} / \mathbf{l}\end{array}$} & $\begin{array}{c}\text { Minimum inhibitory concentrations }(\boldsymbol{\mu g} / \mathbf{m l}) \\
\text { relative }\end{array}$ \\
\cline { 3 - 6 } & $\begin{array}{c}\text { Bacillus } \\
\text { subtilis } \\
\text { BT-2 } \\
\text { (spores) }\end{array}$ & $\begin{array}{c}\text { Entero- } \\
\text { bacter } \\
\text { cloacae } \\
\text { C-8 }\end{array}$ & $\begin{array}{c}\text { Staphylo- } \\
\text { coccus } \\
\text { aureus } \\
\text { BMS-1 }\end{array}$ & $\begin{array}{c}\text { Candida } \\
\text { albicans } \\
\text { D-6 }\end{array}$ \\
\hline \multirow{2}{*}{$\begin{array}{c}\text { Waste of } \\
\text { biodiesel } \\
\text { production }\end{array}$} & 0 & 29.7 & 29.7 & 59.5 & 59.5 \\
\cline { 2 - 6 } & 0.1 & 88.7 & 44.4 & 88.7 & 355 \\
\hline \multirow{2}{*}{$\begin{array}{c}\text { Purified } \\
\text { glycerol }\end{array}$} & 0.2 & 29.4 & 29.4 & 14.7 & 14.7 \\
\cline { 2 - 6 } & 0 & 3.67 & 1.83 & 58.8 & 29.4 \\
\cline { 2 - 6 } & 0.1 & 2.65 & 1.33 & 21.3 & 21.3 \\
\hline
\end{tabular}

Note. When determining the minimum inhibitory concentration, the error did not exceed 5\%.

The detected dependence of the antimicrobial activity of surfactants synthesized on the waste of biodiesel production on the concentration of calcium cations in the medium can be explained for the following reasons. First, given the presence of monovalent cations potential inhibitors of $\mathrm{NADH}^{+}$-dependent glutamate dehydrogenase in biodiesel waste, may be required a higher concentration of calcium cations to activate this enzyme. Secondly, apparently, the strain IMV B-7241 has several glutamate dehydrogenases that are activated by different concentrations of calcium cations.

Our previous studies (Pirog et al., 2019) of the effect of different concentrations of calcium cations on the antimicrobial activity of surfactants synthesized during the cultivation of A. calcoaceticus IMV B-7241 on ethanol showed that the minimum inhibitory concentration against bacteria (Escherichia coli IEM-1, B. subtilis BT-2, E. cloaceae C-8, Proteus vulgaris PA-12) surfactants formed on a medium with $0.1 \mathrm{~g} / 1 \mathrm{CaCl}_{2}$, was $1.3-3.5$ times lower, than MIC surfactants synthesized in the base medium (4-32 and 14-56 $\mu \mathrm{g} / \mathrm{ml}$, respectively).

Note that in the literature information on the antimicrobial activity of surfactants synthesized on refined glycerol are few and relate to lipopeptides synthesized by bacteria of the genus Bacillus (Das et al., 2009; Singh et al., 2014), and rhamnolipids synthesized by representatives of the genus Pseudomonas and Halomonas (Alvionita and Hertadi, 2019; Buonocore et al., 2020). However, minimal inhibitory concentrations of surfactants Bacillus circulans (Das et al., 2009), Bacillus amylofaciens AR2 (Singh et al., 2014) and Bacillus thuringiensis pak2310 (Deepak and Jayapradha, 2015) against bacteria (E. coli NCIM 2931, Micrococcus flavus 2376, P. vulgaris NCIM 2857 and S. aureus MRS) and fungi (Aspergillus niger, C. albicans, Fusarium solani ATCC 36031, Fusarium oxysporum MTCC 7229, 
Alternaria alternata MTCC 2724, Alternaria citri MTCC 4875, Cladosporium cladispororecopular ATCC 160 ATCC 58636, Microsporum gypseum MTCC 4522, Trichophyton rubrum MTCC 296) were in the range of 50-750 $\mu \mathrm{g} / \mathrm{ml}$, which is significantly higher than the values, established for our studied surfactants $A$. calcoaceticus IMV B-7241 (see Table 1). The MIC of rhamnolipids relative to bacterial (S. aureus 6538P, Bacillus cereus, Listeria monocytogenes, Staphylococcus epidermidis, Stenotrophomonas maltophilia 13637) and fungal (T. rubrum, Trichophyton mentagrophytes) test cultures were 3.13-433 $\mu \mathrm{g} / \mathrm{ml}$ (Buonocore et al., 2020; Sen et al., 2020) and were higher than the minimum inhibitory indexes of surfactant $A$. calcoaceticus IMV B-7241 (see Table 1).

To date, we have found only one work in the available literature that investigated the antimicrobial activity of surfactants synthesized on biodiesel waste (Bharali et al., 2014). However, the authors of this work determined the antimicrobial activity of rhamnolipids synthesized by Pseudomonas aeruginosa JBK1 by the method of diffusion into agar, so compare their data with those given in table 1 does not seem possible.

Therefore, our results point out the possibility of regulating the antimicrobial activity of A. calcoaceticus surfactants IMV B-7241 synthesized in the medium with glycerol different degrees of purification by adding calcium cations and are consistent with the preliminary results of cultivation strain IMV B-7241 on medium with ethanol and different concentrations of $\mathrm{Ca}^{2+}$ (Pirog et al., 2019).

\section{Influence of calcium cations on anti-adhesive activity of surfactants}

The data shown in table 2 indicate that the additional introduction of calcium cations into the medium with refined glycerol was accompanied by the synthesis of surfactants with increased anti-adhesive activity.

Thus, under the action of surfactants synthesized in such medium, the adhesion $S$. aureus BMS-1 to abiotic materials was $3-28 \%$ and was lower than in the presence of surfactants formed in a medium without calcium cations $-11-33 \%$. In the case of adding of $0.2 \mathrm{~g} / \mathrm{l} \mathrm{CaCl}_{2}$ into the medium with the waste of biodiesel production, the synthesis of surfactants was observed, in the presence of which the adhesion of S. aureus BMS-1 on tiles, steel and glass was only $7-25 \%$, while the anti-adhesive activity of surfactants, synthesized in a medium without calcium cations, was lower: the degree of adhesion was $10-64 \%$ (Table 2).

Similar patterns were observed during the study of the anti-adhesive activity of surfactants against $B$. subtilis BT-2. The adhesion of this test culture cells on abiotic surfaces treated with surfactant solutions synthesized in a medium with calcium chloride was 26$45 \%$, that is lower than after the treatment of surfactants obtained on a base medium (31$48 \%)$. At the same time, the number of $E$. cloacae C-8 cells attached to the surfaces decreased (compared to the control) by several percent only in the case of their treatment with surfactants synthesized in the presence of $0.2 \mathrm{~g} / \mathrm{l}$ in the medium. Note that only at the lowest concentration of surfactants $(0.55 \mu \mathrm{g} / \mathrm{ml})$ synthesized in the presence of $0.2 \mathrm{~g} / 1$ of calcium chloride, a decrease of $12-13 \%$ in the adhesion of C. albicans D-6 on tiles and steel in compared with the indicators established for surfactants obtained on the base medium. Note that such patterns were observed for surfactants synthesized on both refined glycerol and waste of biodiesel production.

The obtained data points out that the anti-adhesive activity of surfactants depends on many factors: the concentration of surfactants, the type of abiotic surface and the type of test cultures. In addition, no direct correlation was found between the antimicrobial and antiadhesive activity of surfactants synthesized under different culture conditions of $A$. 
calcoaceticus IMV B-7241. It is obvious that the anti-adhesive action of microbial surfactants is based not only on antimicrobial activity but also on other mechanisms (for example, changes in the surface charge of cells or the surface).

Table 2

Effect of $A$. calcoaceticus IMV B-7241 surfactant, synthesized in a medium with different content of calcium cations, on the adhesion of Staphylococcus aureus BMS-1 to different surfaces

\begin{tabular}{|c|c|c|c|c|c|}
\hline \multirow{2}{*}{ Carbon source } & \multirow{2}{*}{$\begin{array}{c}\text { Contents } \\
\mathrm{CaCI}_{2}, \mathrm{~g} / \mathbf{l} \\
\end{array}$} & \multirow{2}{*}{$\begin{array}{c}\text { Surfactant } \\
\text { concentration, } \mu \mathrm{g} / \mathrm{ml}\end{array}$} & \multicolumn{3}{|c|}{ Adhesion, \% } \\
\hline & & & Tile & Steel & Glass \\
\hline \multirow{15}{*}{$\begin{array}{c}\text { Waste of biodiesel } \\
\text { production }\end{array}$} & \multirow{5}{*}{0} & 8.87 & 23 & 11 & 10 \\
\hline & & 4.43 & 51 & 17 & 17 \\
\hline & & 2.2 & 55 & 19 & 21 \\
\hline & & 1.1 & 58 & 28 & 21 \\
\hline & & 0.55 & 64 & 33 & 24 \\
\hline & \multirow{5}{*}{0,1} & 8.87 & 62 & 6 & 10 \\
\hline & & 4.43 & 68 & 14 & 24 \\
\hline & & 2.20 & 70 & 14 & 24 \\
\hline & & 1.10 & 77 & 22 & 38 \\
\hline & & 0.55 & 83 & 25 & 52 \\
\hline & \multirow{5}{*}{0,2} & 8.87 & 17 & 25 & 10 \\
\hline & & 4.43 & 11 & 22 & 7 \\
\hline & & 2.20 & 8 & 14 & 10 \\
\hline & & 1.10 & 9 & 14 & 7 \\
\hline & & 0.55 & 9 & 8 & 7 \\
\hline \multirow{15}{*}{ Refined glycerol } & \multirow{5}{*}{0} & 8.87 & 19 & 13 & 11 \\
\hline & & 4.43 & 25 & 17 & 17 \\
\hline & & 2.20 & 25 & 23 & 25 \\
\hline & & 1.10 & 30 & 23 & 25 \\
\hline & & 0.55 & 33 & 27 & 30 \\
\hline & \multirow{5}{*}{0,1} & 8.87 & 15 & 11 & 10 \\
\hline & & 4.43 & 15 & 15 & 11 \\
\hline & & 2.20 & 20 & 19 & 19 \\
\hline & & 1.10 & 23 & 19 & 25 \\
\hline & & 0.55 & 28 & 26 & 32 \\
\hline & \multirow{5}{*}{0,2} & 8.87 & 13 & 8 & 3 \\
\hline & & 4.43 & 19 & 11 & 14 \\
\hline & & 2.20 & 23 & 14 & 17 \\
\hline & & 1.10 & 28 & 19 & 21 \\
\hline & & 0.55 & 28 & 25 & 28 \\
\hline
\end{tabular}

Note. When determining adhesion, the error did not exceed 5\%.

Despite the information on the antimicrobial activity of surfactants synthesized on glycerol, in the available literature there is much less information about their anti-adhesive action. 
In (Chebbi et al., 2017) it was found that the degree of adhesion of Bacillus licheniformis CAN55 and Staphylococcus capitis SH6 was 15 and $35 \%$, respectively, on polystyrene after treatment with solutions of rhamnolipids $P$. aeruginosa W10 synthesized on refined glycerol at a concentration of $3125 \mu \mathrm{g} / \mathrm{ml}$.

The amount of adherent S. aureus ATCC 29523, B. cereus MTCC 7190, Salmonella typhimurium ATCC 19430 cells to a polystyrene surface treated with solutions of $B$. subtilis VSG4 lipopeptides obtained on refined glycerol $(3000 \mu \mathrm{g} / \mathrm{ml})$ was in the range of $33-40 \%$ (Giri et al., 2019).

Therefore, synthesized in both base and modified medium with refined glycerol and waste of biodiesel production surfactants $A$. calcoaceticus IMV B-724 are significantly more effective anti-adhesive agents than those described in (Chebbi et al., 2017; Giri et al., 2019) because they show anti-adhesive activity in orders of magnitude lower concentrations $(0.55-8.87 \mu \mathrm{g} / \mathrm{ml})$.

\section{Destruction of biofilms under the action of surfactants synthesized in an medium with different concentrations of calcium cations}

Surfactants of microbial origin also have the ability to destroy biofilms in addition to antimicrobial and anti-adhesive activity. Therefore, the destruction of bacterial and yeast biofilms under the action of $A$. calcoaceticus IMV B-7241 surfactants, synthesized in medium of different compositions were studied in the next step.

The results showed that surfactants synthesized in a medium with refined glycerol and $\mathrm{CaCl}_{2}$ were more effective in destroying bacterial and yeast biofilms than surfactants obtained on a similar base medium without calcium cations (Tables 3-6).

Table 3

Destruction of Enterobacter cloacae C-8 biofilm by the action of surfactants synthesized on glycerol

\begin{tabular}{|c|c|c|c|c|}
\hline \multirow{3}{*}{ Carbon source } & $\begin{array}{c}\text { Concentration } \\
\mathbf{C a C I}_{\mathbf{2}} \mathbf{( g / \mathbf { l } )}\end{array}$ & \multicolumn{3}{|c|}{$\begin{array}{c}\text { Destruction of biofilm (\%) under the } \\
\text { action of surfactants at a concentration } \\
(\boldsymbol{\mu g} / \mathbf{m l})\end{array}$} \\
\cline { 2 - 5 } & & 5.5 & 1.4 & 0.7 \\
\hline \multirow{3}{*}{$\begin{array}{c}\text { Waste of biodiesel } \\
\text { production }\end{array}$} & 0 & 38.6 & 32.9 & 21.6 \\
\cline { 2 - 5 } & 0.1 & 48.8 & 41.0 & 33.8 \\
\cline { 2 - 5 } & 0.2 & 54.5 & 46.3 & 41.0 \\
\hline \multirow{3}{*}{ Refined glycerol } & 0 & 68.7 & 71.5 & 75.6 \\
\cline { 2 - 5 } & 0.1 & 56.0 & 83.4 & 86.5 \\
\cline { 2 - 5 } & 0.2 & 92.0 & 93.2 & 93.9 \\
\hline
\end{tabular}

Note. Table. 3-6: when determining the destruction of the biofilm, the error did not exceed 5\%. 
Table 4

Effect of calcium cations content in the culture medium of $A$. calcoaceticus IMV B-7241 on the ability of synthesized surfactants to destroy the biofilm of Bacillus subtilis BT-2

\begin{tabular}{|c|c|c|c|c|c|c|c|}
\hline \multirow{2}{*}{$\begin{array}{c}\text { Carbon } \\
\text { source }\end{array}$} & $\begin{array}{c}\text { Concentration } \\
\text { CaCI2 (g/l) }\end{array}$ & \multicolumn{4}{|c|}{$\begin{array}{c}\text { Destruction of biofilm (\%) under the action of } \\
\text { surfactants at a concentration }(\boldsymbol{\mu g} / \mathbf{m l})\end{array}$} \\
\cline { 3 - 9 } & & $\mathbf{4 4 . 3}$ & $\mathbf{2 2 . 2}$ & $\mathbf{5 . 5}$ & $\mathbf{2 . 7}$ & $\mathbf{1 . 4}$ & $\mathbf{0 . 7}$ \\
\hline \multirow{2}{*}{$\begin{array}{c}\text { Waste of } \\
\text { biodiesel } \\
\text { production }\end{array}$} & 0 & 52.6 & 45.3 & 37.1 & 33.7 & 33.7 & 30.0 \\
\cline { 2 - 9 } & 0.1 & 33.7 & 36.8 & 38.2 & 40.3 & 41.4 & N.d. \\
\cline { 2 - 9 } & 0.2 & 38.9 & 41.3 & 42.3 & 45.6 & 48.7 & 49.4 \\
\hline \multirow{2}{*}{$\begin{array}{c}\text { Refined } \\
\text { glycerol }\end{array}$} & 0 & 44.2 & 51.6 & 59.7 & 72.3 & 78.5 & N.d. \\
\cline { 2 - 8 } & 0.1 & 45.1 & 56.7 & 64.7 & 79.2 & 85.2 & N.d. \\
\cline { 2 - 8 } & 0.2 & 57.4 & 63.1 & 72.4 & 85.2 & 87.3 & N.d. \\
\hline
\end{tabular}

Note. N.d. - not determined.

Table 5

Destruction of Staphylococcus aureus BMS-1 biofilm under the influence of $\boldsymbol{A}$. calcoaceticus IMV B-7241 surfactants, synthesized in a medium with different content of calcium cations

\begin{tabular}{|c|c|c|c|c|}
\hline \multirow{2}{*}{ Carbon source } & \multicolumn{2}{|c|}{$\begin{array}{c}\text { Concentration } \\
\text { CaCI } \mathbf{2}(\mathbf{g} / \mathbf{l})\end{array}$} & \multicolumn{3}{|c|}{$\begin{array}{c}\text { Destruction of biofilm (\%) under the } \\
\text { action of surfactants at a concentration } \\
(\boldsymbol{\mu} \mathbf{g} / \mathbf{m l})\end{array}$} \\
\cline { 2 - 5 } & 0 & $\mathbf{4 4 . 3}$ & $\mathbf{2 . 7}$ & $\mathbf{1 , 4}$ \\
\hline \multirow{2}{*}{$\begin{array}{c}\text { Waste of } \\
\text { biodiesel } \\
\text { production }\end{array}$} & 0.1 & 28.8 & 28.8 & 31.7 \\
\cline { 2 - 5 } & 0.2 & 29.5 & 30.5 & 33.7 \\
\hline \multirow{3}{*}{ Refined glycerol } & 0 & 38.1 & 40.4 & 43.7 \\
\cline { 2 - 5 } & 0.1 & 74.5 & 54.7 & 45.6 \\
\cline { 2 - 5 } & 0.2 & 94.3 & 64.3 & 56.1 \\
\hline
\end{tabular}

Antibiofilm activity against Candida albicans D-6 surfactants synthesized

Table 6 by $A$. calcoaceticus IMV B-7241

\begin{tabular}{|c|c|c|c|c|c|}
\hline \multirow[t]{2}{*}{ Carbon source } & \multirow[t]{2}{*}{$\begin{array}{c}\text { Concentration } \\
\mathrm{CaCI}_{2}(\mathrm{~g} / \mathrm{l})\end{array}$} & \multicolumn{4}{|c|}{$\begin{array}{l}\text { Destruction of biofilm }(\%) \text { under the } \\
\text { action of surfactants at a concentration } \\
\qquad(\mu \mathrm{g} / \mathrm{ml})\end{array}$} \\
\hline & & 22.2 & 5.5 & 1.4 & 0.7 \\
\hline \multirow{3}{*}{$\begin{array}{l}\text { Waste of } \\
\text { biodiesel } \\
\text { production }\end{array}$} & 0 & 71.4 & 60.2 & 53.0 & 52.1 \\
\hline & 0.1 & 25.5 & 33.7 & 37.7 & 40.8 \\
\hline & 0.2 & 33.7 & 43.9 & 45.1 & 48.2 \\
\hline \multirow{3}{*}{ Refined glycerol } & 0 & 79.1 & 78.1 & 76.5 & 72.3 \\
\hline & 0.1 & 88.6 & 86.5 & 84.4 & 78.2 \\
\hline & 0.2 & 95.8 & 94.0 & 91.8 & 84.7 \\
\hline
\end{tabular}


Thus, under the action of surfactants synthesized in a medium with 0.1 and $0.2 \mathrm{~g} / 1$ of calcium chloride, the destruction of biofilms was on average 5-10 and $12-19 \%$, respectively, higher than in the presence of surfactants obtained on a medium without $\mathrm{CaCI}_{2}$.

Note that the destruction of biofilms of all studied test cultures was 6-12\% higher under the influence of surfactants synthesized in a medium with refined glycerol containing $0.2 \mathrm{~g} / \mathrm{l}$ of calcium chloride than under the action of surfactants obtained on a similar medium with $0.1 \mathrm{~g} / \mathrm{CaCl}_{2}$. In addition, a high degree of biofilms destruction (on average 70-90\%) was achieved at low $(0.7-5.5 \mu \mathrm{g} / \mathrm{ml})$ concentrations of surfactants synthesized on refined glycerol.

Slightly different patterns were observed during the study of the biofilms destruction by surfactants obtained on the waste of biodiesel production with different calcium chloride content (see Tables 3-6). First, surfactants synthesized in the medium with calcium cations proved to be more effective destructors of bacterial biofilms compared to those obtained in the base medium only at low concentrations $(0.7-5.5 \mu \mathrm{g} / \mathrm{ml})$. Second, the additional introduction of calcium chloride into the medium with the waste of biodiesel production was accompanied by the formation of surfactants, which were characterized by a lower ability to destroy yeast biofilm than synthesized in the base medium: the degree of destruction $C$. albicans D-6 biofilm was $25-48$ and $52-71 \%$ respectively (see table. 6). In addition, surfactants obtained under different conditions of $A$. calcoaceticus IMV B-7241 cultivation on the waste of biodiesel production have a lower ability to destroy bacterial and yeast biofilms than those synthesized on refined glycerol (destruction 21-71 and 56-96 accordingly, see Tables 3-6).

There is limited data in the literature on the ability of surfactants synthesized in a glycerol-containing medium to destroy microbial biofilms. Giri et al. (2019) found that the destruction of biofilms of $S$. aureus ATCC 29523, E. coli MTCC 65, S. typhimurium ATCC 19430 was in the range of $58-78 \%$ in the presence of lipopeptides $B$. subtilis VSG4 in a sufficiently high concentration $(3000-5000 \mu \mathrm{g} / \mathrm{ml})$. The destruction of the biofilm of $F$. oxysporum (strain not specified) was observed by $58 \%$ in the presence of $500 \mu \mathrm{g} / \mathrm{ml}$ lipopeptides of B. thuringiensis pak2310 (Deepak and Jayapradha, 2015). The work of Sen et al. (2020) show that the destruction of biofilms of fungi T. rubrum MTCC 8477 and $T$. mentagrophytes NCCPF 800049 reached $80-85 \%$ under the influence of rhamnolipids at a concentration of 2000 and $250 \mu \mathrm{g} / \mathrm{ml}$, respectively. De Rienzo and Martin (2016) found that rhamnolipids of Burkholderia thailandensis E264 at a concentration of $400 \mu \mathrm{g} / \mathrm{ml}$ are able to destroy the biofilm of $B$. subtilis BBK066. In this work, the destruction of the biofilm was examined visually using confocal microscopy, and the degree of its destruction by the authors is not given.

Thus, described in the literature the rhamnolipids and lipopeptides synthesized on purified glycerol, destroy $58-85 \%$ of bacterial and fungal biofilms at sufficiently high concentrations (400-5000 $\mu \mathrm{g} / \mathrm{ml}$ ). Our results (see Table 3-6) show that the same degree of destruction of bacterial and yeast biofilms is achieved by the action of $A$. calcoaceticus IMV B-7241 surfactants in much lower (several orders of magnitude) concentrations (0.7-44, 3 $\mu \mathrm{g} / \mathrm{ml})$.

\section{Conclusion}

1. The results demonstrate the possibility tof regulate the biological activity of surfactants produced by A. calcoaceticus IMB B-7241 by changing in the composition of medium with refined glycerol and waste of biodiesel production content of calcium cations, which are activators of $\mathrm{NADH}^{+}$-dependent glutamate dehydrogenase (key enzyme of surface-active aminolipids biosynthesis). 
2. Surfactants synthesized under different cultivation conditions by $A$. calcoaceticus IMB B-7241 on refined glycerol and waste of biodiesel production are more effective biofilm destructors and antimicrobial and anti-dhesive agents compared to the known lipopeptides and rhamnolipids formed on glycerol.

\section{References}

Alvionita M., Hertadi R. (2019), Bioconversion of glycerol to biosurfactant by halophilic bacteria Halomonas elongata BK-AG18, Indonesian Journal of Chemistry, 19, pp. 4857.

Bharali P., Singh S.P., Dutta N., Gogoi S., Bora L.C., Debnath P., Konwar B.K. (2014), Biodiesel derived waste glycerol as an economic substrate for biosurfactant production using indigenous Pseudomonas aeruginosa, RSC Advances, 4(73), pp. 38698-38706, DOI: $10.1039 / \mathrm{c} 4 \mathrm{ra} 05594 \mathrm{~b}$.

Bligh E.G., Dyer W.J. (1959), A rapid method for total lipid extraction and purification, Canadian Journal of Biochemistry and Physiology, 37(8), pp. 911-917.

Buonocore C., Tedesco P., Vitale G.A., Esposito F.P., Giugliano R., Monti M.C., D’Auria M.V., de Pascale D. (2020), Characterization of a new mixture of mono-rhamnolipids produced by Pseudomonas gessardii isolated from Edmonson Point (Antarctica), Marine Drugs, 18, DOI: 10.3390/md18050269.

Chebbi A., Elshikh M., Haque F., Ahmed S., Dobbin S., Marchant R., Sayadi S., Chamkha M., Banat I.M. (2017), Rhamnolipids from Pseudomonas aeruginosa strain W10; as antibiofilm/antibiofouling products for metal protection, Journal of Basic Microbiology, 57(5), pp. 364-375, DOI: 10.1002/jobm.201600658.

Crosse A.J., Brady D., Zhou N., Rumbold K. (2019), Biodiesel's trash is a biorefineries' treasure: the use of «dirty» glycerol as an industrial fermentation substrate, World Journal of Microbiology \& Biotechnology, 36(1), DOI: 10.1007/s11274-019-2776-9.

Das P., Mukherjee S., Sen R. (2009), Substrate dependent production of extracellular biosurfactant by a marine bacterium, Bioresource Technology, 100(2), pp. 1015-1019, DOI: 10.1016/j.biortech.2008.07.015.

Deepak R., Jayapradha R. (2015), Lipopeptide biosurfactant from Bacillus thuringiensis pak2310: a potential antagonist against Fusarium oxysporum, Journal de Mycologie Médicale, 25(1), pp.15-24, DOI: 10.1016/j.mycmed.2014.10.011.

De Rienzo M.A.D., Martin P.J. (2016), Effect of mono- and di-rhamnolipids on biofilms preformed by Bacillus subtilis BBK006, Current Microbiology, 73(2), pp. 183-189, DOI: 10.1007/s00284-016-1046-4.

Diamantopoulou P., Filippousi R., Antoniou D., Varfi E., Xenopoulos E., Sarris D., Papanikolaou S. (2020), Production of added-value microbial metabolites during growth of yeast strains on media composed of biodiesel-derived crude glycerol and glycerol/xylose blends, FEMS Microbiology Letters, 367(10), DOI: 10.1093/femsle/fnaa063.

Giri S.S., Ryu E., Sukumaran V., Chang Park S. (2019), Antioxidant, antibacterial, and antiadhesive activities of biosurfactants isolated from Bacillus strains, Microbial Pathogenesis, 132, pp. 66-72, DOI: 10.1016/j.micpath.2019.04.035.

Gomes M.Z.V., Nitschke M. (2012), Evaluation of rhamnolipids surfactants as agents to reduce the adhesion of Staphylococcus aureus to polystyrene surfaces, Letters in 
Applied Microbiology, 49(1), pp. 960-965.

Pirog T.P., Lutsai D.A., Shevchuk T.A., Iutynska G.O., Elperin I.V. (2018), Antimicrobial and anti-adhesive activity of surfactants synthesized by Acinetobacter calcoaceticus IMV B-7241 on technical glycerol, Mikrobiologichny Zhurnal, 80(2), pp. 14-27, DOI: 10.15407/microbiolj80.02.014.

Pirog T.P., Shevchuk T.A., Nikituk L.V., Lutsai D.A., Paliichuk O.I. (2018), Influence of cultivation conditions on antimicrobial and anti-adhesive activity of surfactants of bacteria of Acinetobacter, Rhodococcus and Nocardia genera. Proceedings of the National Academy of Sciences of Belarus. Biological series, 63(3), pp. 307-315. 10.29235/1029-8940-2018-63-3-307-315.

Pirog T.P., Kliuchka L.V., Shevchuk T.A., Muchnyk F.V. (2019), Interrelation of chemical composition and biological properties of microbial surfactants, Mikrobiologichny Zhurnal, 81(3), pp. 84-104, DOI: 10.15407/microbiolj81.03.084.

Pirog T., Kluchka L., Lytsai D., Stabnikov V. (2021a), Factors affecting antibiofilm properties of microbial surfactants, Scientific Study \& Research: Chemistry \& Chemical Engineering, Biotechnology, Food Industry, 21(1), pp. 27-37.

Rufino R.D., Luna J.M., Sarubbo L.A., Rodrigues L.R., Teixeira J.A., Campos-Takaki G.M. (2011), Antimicrobial and anti-adhesive potential of a biosurfactant Rufisan produced by Candida lipolytica UCP 0988, Colloids and Surfaces B: Biointerfaces, 84(1), pp.1-5, DOI: 10.1016/j.colsurfb.2010.10.045.

Sen S., Borah S.N., Bora A., Deka S. (2020), Rhamnolipid exhibits anti-biofilm activity against the dermatophytic fungi Trichophyton rubrum and Trichophyton mentagrophytes, Biotechnology Reports, 27, DOI: 10.1016/j.btre.2020.e00516.

Sharma P., Sharma N. (2021), Microbial biosurfactants - an ecofriendly boon to industries for green revolution, Recent Patents on Biotechnology, 14(3), pp.169-183, DOI: 10.2174/1872208313666191212094628.

Shu Q., Lou H., Wei T., Liu X., Chen Q. (2021), Contributions of glycolipid biosurfactants and glycolipid-modified materials to antimicrobial strategy: a review, Pharmaceutics, 13(2), DOI: 10.3390/pharmaceutics13020227.

Singh A., Rautela R., Cameotra S. (2014), Substrate dependent in vitro antifungal activity of Bacillus sp strain AR2, Microbial Cell Factories, 13(1), DOI: 10.1186/1475-2859-1367. 